\title{
The Evolving Responsibilities, Roles, and Competencies of East Asian Studies Librarians: A Content Analysis of Job Postings from 2008 to 2019
}

\section{Xiang Li and Tang Li}

\begin{abstract}
A content analysis of 62 job postings for East Asian studies librarians in the United States and Canada during 2008-2019 demonstrates that major job responsibilities have expanded to include collection development and management, reference and research assistance, instruction, liaison work, and outreach; relationship building and collaboration are emerging roles; skills and abilities have been progressively occupying a larger proportion than knowledge and experience in the required qualifications; top frequently required abilities and skills are generic and behavioral; and professional experiences are often preferred rather than required. The results of this research are of practical relevance to subject specialists in other areas.
\end{abstract}

\section{Introduction}

In his influential article entitled "Raised by Wolves: Integrating the New Generation of Feral Professionals in the Academic Library," James Neal discussed how academic libraries were hiring an increasing number of new librarians with diverse educational backgrounds and qualifications, who brought to the academic library " a 'feral' set of values, outlooks, styles, and expectations." ${ }^{1}$ Certainly, rapid and significant developments in information technologies have transformed academic libraries and consequently created a wide range of new professional positions that would require training and experience in nontraditional librarianship areas. But what about the traditional librarian positions, more specifically, the area studies librarian positions? In what ways have the technology revolution, the changing nature of library work, and the emergence of new types of positions shifted the job focus and qualification requirements for area studies librarians?

Area studies librarians are of particular importance to investigating the changing academic library landscape, as they were a major precursor of subject librarians, one of the pillars that

\footnotetext{
*Xiang Li is an Associate Professor and Chinese \& Asian Studies Librarian in the University Libraries at the University of Colorado Boulder; email: Xiang.li@colorado.edu. Tang Li is Chinese Studies Librarian at the University of Southern California Libraries; email: tangl@usc.edu. The authors would like to gratefully thank the following colleagues for reviewing and providing thoughtful feedback on early drafts of this paper: Kenneth Klein, University of Southern California; Jennifer Knievel, University of Colorado Boulder; Megan Welsh, University of Colorado Boulder; Peter Zhou, University of California, Berkeley. (2021 Xiang Li and Tang Li, Attribution-NonCommercial (https://creativecommons.org/licenses/by-nc/4.0/) CC BY-NC.
} 
helped define an academic library. Subject librarianship as a focus within the profession evolved from the development of area studies in the United States after World War II. ${ }^{2}$ The area studies approach valued the importance of building in-depth and readily accessible library collections on foreign regions and cultures, leading to the creation of area studies librarian positions in academic libraries. These positions required subject expertise and language fluency in specific geographic areas. Soon after, as subject librarians in area studies made significant impacts on academic librarianship, new positions of subject librarians in non-area studies disciplines were created at major university libraries. The brief history of the subject librarian model shows that subject librarianship in the United States was born with professional characteristics in line with those of area studies librarianship. At the core of the subject librarian's role is expertise on a particular subject or academic discipline.

The divisional library structure, which originated in the 1960s and allocates library collection spaces (such as reading rooms and reference collections) and budgets along subject and discipline lines, can be attributed to the development of the subject librarian model. ${ }^{3}$ As Hay noted, this organizational structure allowed subject librarians to facilitate their involvement in every aspect of librarianship pertaining to their subject specialties. ${ }^{4}$ The subject-divisional approach continues to be an important part of library organizational structure for most university libraries.

Nevertheless, in today's rapidly changing information environment, the subject-divisional approach is facing the challenges of a shift toward a functional specialist model, which focuses on librarians performing particular functions, such as teaching and learning support, data management, marketing and relationship management, and other functions across different disciplines. ${ }^{5}$ Many academic libraries in the past decades have transitioned to a "hybrid model" that combines elements of subject experts and functional specialists. ${ }^{6}$ This hybrid approach echoes Neal's observation of the emerging new professionals who were trained in areas as systems, publishing, instructional technology, and other specialties. ${ }^{7}$ However, little has been studied on how area studies librarians' jobs have changed under this new organizational structure, which is no longer based solely on academic discipline divisions.

The present study focuses on East Asian studies librarians, a major subgroup of area studies librarians, and analyzes 62 job postings for East Asian studies librarians from academic libraries in the United States and Canada during 2008-2019. It intends to investigate characteristics and changes in the job descriptions and qualifications and to understand and envision the future development of East Asian studies librarianship and, more broadly, subject librarianship. The research questions that guided this study are as follows: In what ways has the East Asian studies librarian's job been changing? What qualifications are needed for an East Asian studies librarian to perform their job? Is subject expertise still the core value for an East Asian studies librarian? What might be the trends for East Asian studies librarian roles in the new digital age?

\section{Literature Review}

There has been extensive literature in the last 30 years that analyzes librarian job postings and examines the state of, changes to, and trends in the academic library profession. The following review of pertinent literature sets the present study in the broader context of a changing academic librarianship that has tremendously impacted the knowledge and skills required for academic librarians. 
Researchers started to investigate the broad spectrum of academic librarian positions in the 1990s. Reser and Schuneman analyzed 1,133 academic library job postings advertised in $1988 .^{8}$ The authors revealed significant differences between public and technical services positions based on variables including "levels of computer skills, foreign-language requirements, previous work experience, educational requirements, and minimum salary offered." ${ }^{9}$ One of the most important findings relevant to the present study is that public service positions were more likely to require advanced degrees in related subject areas. In 2000, Beile and Adams conducted follow-up research focusing on differences among public, technical, and systems positions advertised in $1996 .{ }^{10}$ They detected a steady increase in the number of specialist positions and a rapidly growing demand for computer skills. They also found that public service positions were "approximately three times as likely to require or prefer advanced subject degrees" in comparison to technical and electronic services positions. Recently, in 2015, Triumph and Beile examined 957 academic librarian positions advertised in $2011^{11}$ and compared the results to the previous research on 1988 and 1996 advertisements. This study showed "relative stasis" in some characteristics of advertisements such as educational requirements and prior work experience. Yet, much more dynamic changes were discovered in other areas, including a decline in foreign language skills and an increase in the number of new job titles and requirements in computer skills. The three studies together demonstrated a longterm trend in academic librarianship, which, as Triumph and Beile argued, is that academic library positions are "becoming increasingly specialized." 12

Two longitudinal studies in the 2000s explored emerging roles of academic librarians by analyzing job postings in the College and Research Libraries News. Lynch and Smith examined 220 job postings from 1973 to $1998^{13}$ and noted a rise of requirements for behavioral skills, especially oral and written communication skills, because of the growing needs for academic librarians to interact with library users in various ways. The authors claimed that academic libraries were changing into "an active agency providing information services to users and developing services." ${ }^{14}$ Grimes and Grimes reviewed more than 4,000 job postings from 1975 to 2005 , with a focus on the changing role of the master of library science (MLS) degree in academic libraries. ${ }^{15}$ The study found that the importance of an MLS degree had declined over time, even though it was still essential to public services, technical services, and administrative positions.

The analysis of specific skills (required or desired) or specific types of positions comprise another area of job analysis study. Researchers have been consistently interested in examining certain competencies for academic librarians through the analysis of job postings, such as requirements for information technology skills, ${ }^{16}$ foreign languages, ${ }^{17}$ distance learning skillsets, ${ }^{18}$ and the educational requirements for advanced subject degrees. ${ }^{19}$ There are also many studies that focused on jobs in particular types of libraries or specific librarian positions. ${ }^{20}$ A considerable amount of research has drawn attention to new positions that have emerged as a result of the rapid development of information technology, including digital initiatives librarians, ${ }^{21}$ scholarly communication librarians, ${ }^{22}$ data librarians, ${ }^{23}$ and instructional design librarians. ${ }^{24}$

Of particularly high relevance to the present study is White's 1999 article on subject specialist positions. ${ }^{25}$ Based on his investigation of subject specialist positions in business, social science, and science librarianship from 1990 to 1998, White identified the importance of a second master's degree in addition to the required MLS degree, and that communication 
was the top required skill. In addition, he noted a rising inclusion of electronic resources as responsibilities in job descriptions.

The above review demonstrates that the majority of job posting analysis studies attempt to detect changes and trends in the academic librarian profession as a whole, with a recent emphasis on the newly emerged positions. Yet, little attention has been paid to area studies librarian positions. Alonso-Regalado and Ullen's analysis of Latin American and Caribbean studies (LACS) librarian positions is the only study so far to look closely at area studies librarians' job duties, subject responsibilities, and requirements. ${ }^{26}$ The study concluded with typical requirements for LACS librarians sought by employers and found that a LACS librarian "is now expected to undertake a wider range of duties than in the past, and this trend will likely continue in the future." 27

To date, little research has prioritized investigating the changing role and qualifications of the traditional subject librarian, and no longitudinal study has been published to thoroughly examine East Asian studies librarian positions. The present research contributes to the body of literature in understanding subject librarian jobs and qualifications by employing the content analysis method on job advertisements for East Asian studies librarians from 2008 to 2019.

\section{Methodology Definition}

In this paper, the East Asian studies librarian is defined as a subject specialist librarian whose responsibilities contain East Asian studies in their subject portfolio. "Subject specialist" and "East Asian studies" are the two key factors that set the scope of this study.

The ALA Glossary defines a subject specialist as "a library staff member with superior knowledge of a subject or discipline, with responsibilities for the selection and evaluation of the library's materials in the subject area and sometimes with the added responsibilities of information services in the subject area and the bibliographic organization of the materials. Sometimes called subject bibliographer." ${ }^{28}$ Following this definition, the authors made every effort to exclude jobs that have technical services or administrative duties as their primary responsibilities.

East Asian studies is commonly considered an interdisciplinary field of research and scholarship pertaining to East Asia, which is the eastern subregion of Asia, including mainland China, Japan, North Korea, South Korea, Taiwan, Hong Kong, and Macau. East Asian studies librarians, therefore, may vary in job titles and frequently cover one or more East Asian regions in their major subject areas.

\section{Data Collection}

The job postings under examination in this study were primarily acquired from two sources: Council on East Asian Libraries' website ${ }^{29}$ and archive of Eastlib, ${ }^{30}$ the East Asian studies librarians' email list. These two sources are the major venues for advertising East Asian studies librarian positions in the United States and Canada.

The study eliminated job announcements for temporary or part-time positions. In addition, job announcements from the same institution that had reopened or appeared within 12 months of each other were carefully compared and hence de-duplicated if the content of the two announcements was essentially the same.

As a result, a total of 62 job postings from the 12 years between 2008 and 2019 were included for analysis (see figure 1). 


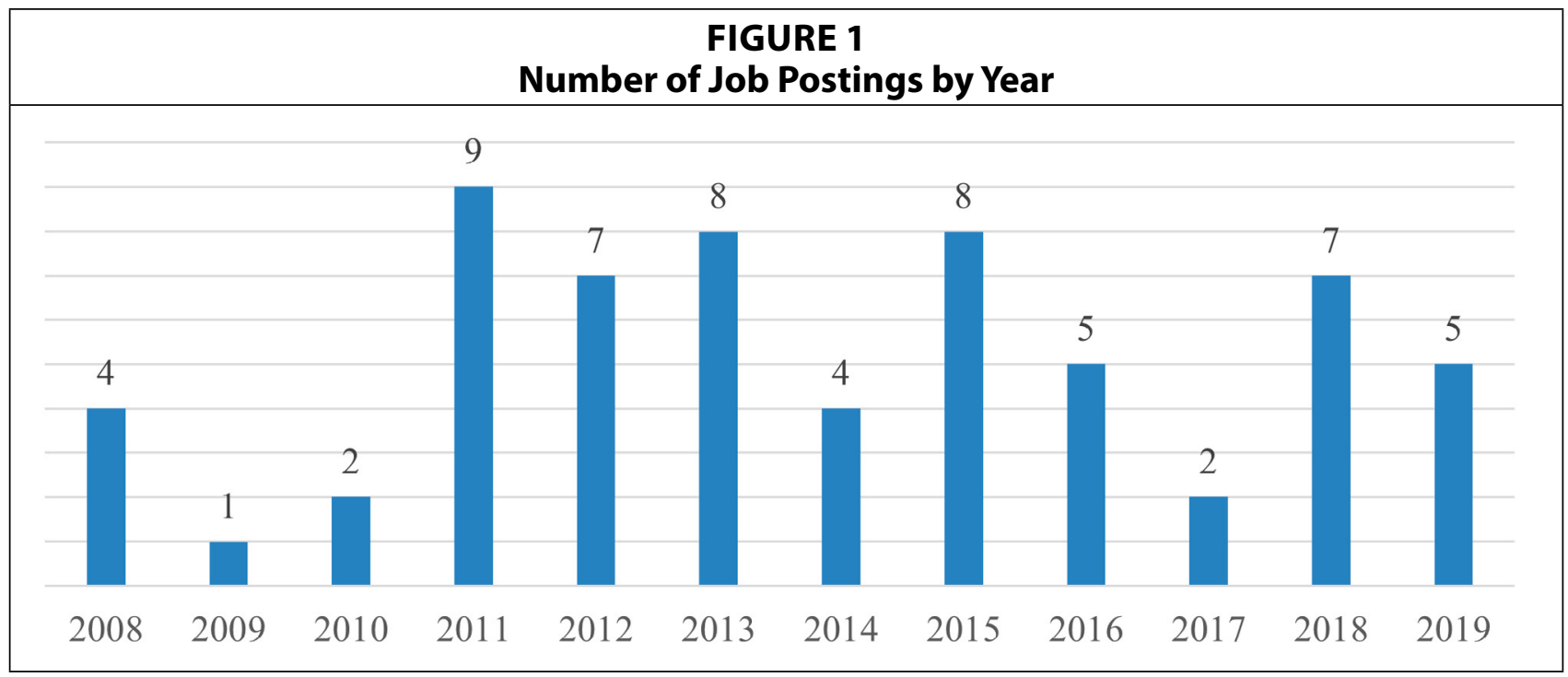

\section{Data Analysis}

The present study chose a content analysis methodology, that is to say "a systematic technique of segmenting data into describable linguistic units," ${ }^{31}$ to obtain objective and quantitative measurements of job postings. The authors divided the corpus into two sections - job description and qualifications - and adopted different data analysis methods for each section. Human coding was performed on the job description section, following the process of content analysis research described in The Content Analysis Guidebook. ${ }^{32}$ Machine learning was conducted on the job qualifications section by using MonkeyLearn, ${ }^{33}$ an online AI platform that allows for training machine learning models to retrieve topics and keywords from raw texts.

The machine learning model is designed to extract and classify keywords and phrases from the raw texts of the qualification sections into six preset and mutually exclusive categories for human resources selection criteria. These six categories are: education, language, knowledge, experience, skills, and abilities (see figure 2). Keywords associated with education and language are relatively easy for the machine learning model to identify and

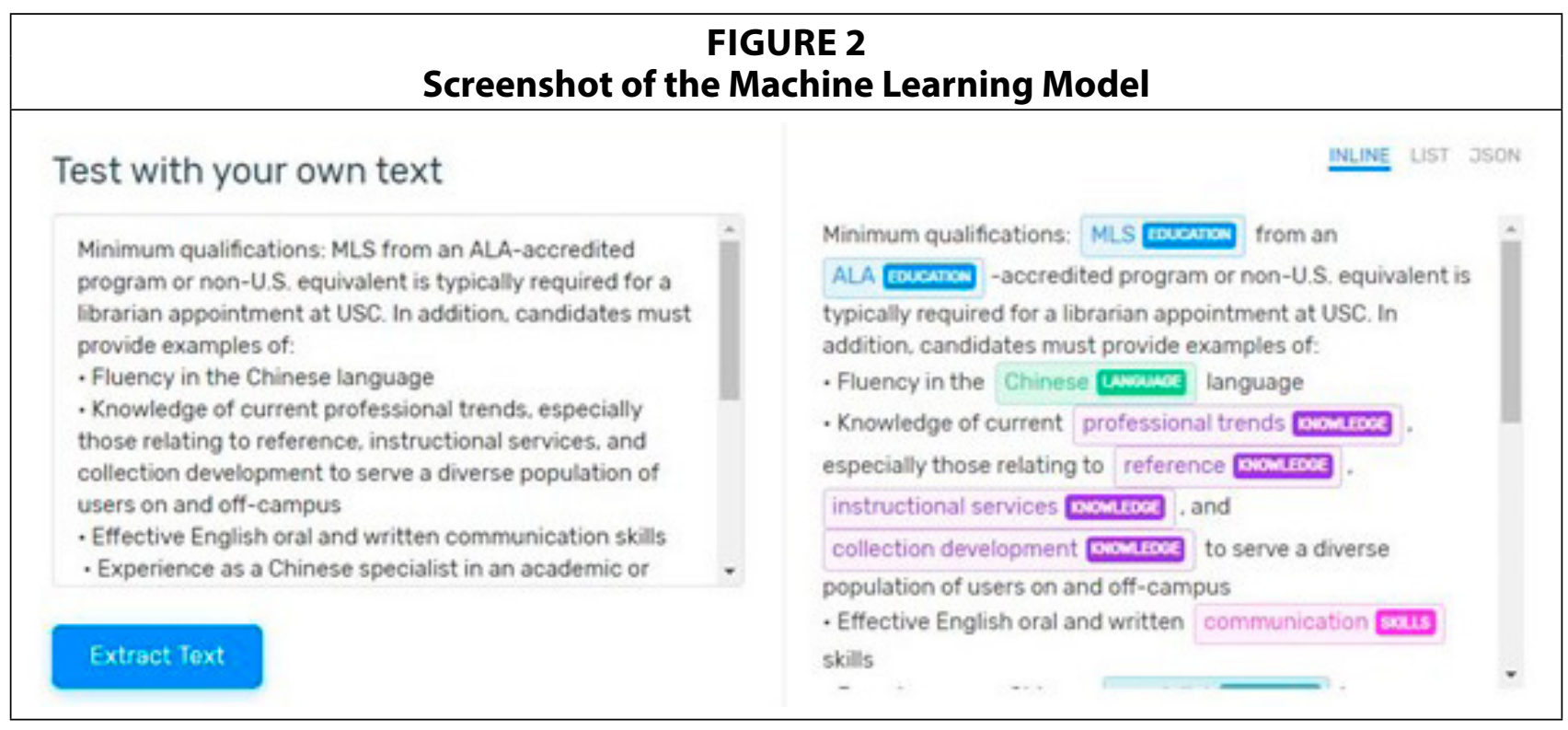


extract, as they often contain standard terms like MLS, advanced degrees, and Chinese/ Japanese/Korean. For complex categories like knowledge, experience, skills, and abilities, the model was specifically trained to recognize cue words (including their commonly used variant forms and synonyms) relating to these four preset categories, and then to extract text next to the cue words and place into a raw data set. Therefore, if the word knowledge (including its synonyms "familiar" and "familiarity") or experience (including its variant "experiences") or skill (including its variant "skills") or ability (including its variants "able" and "abilities") appears in the sentence, the associated texts were extracted and classified as knowledge, experience, skills, or abilities accordingly.

Because the raw texts are small in size, the authors were able to review the text extraction from the machine learning model and consequently found consistently high accuracy and precision of the model. ${ }^{34}$ This model has the potential to be applied to future analysis study of job postings in other subject areas.

To ensure consistency in the data interpretation, the authors created separate coding tables for job descriptions and qualifications to normalize and standardize extracted data from the corpus. These coding tables served as references to define standard forms and terms for words and phrases captured from the raw texts. The authors compared and discussed these coding tables to achieve a final coding scheme that can accurately interpret the texts. In addition, to ensure validity of the coding process, the authors coded the data set multiple times at regular intervals.

\section{Findings}

Job Descriptions Job Responsibilities

As evidently presented in the list of job responsibilities that most frequently appeared in the job postings (see table 1), major responsibilities for East Asian studies librarians are: collection development and management, reference and research assistance, instruction, liaison work, and outreach.

Collection development and management is the top job responsibility; it appeared in all 62 job postings, which suggests that building collections as a primary duty has remained fundamental to East Asian studies librarian positions ever since the 1960s, when American university libraries started to adopt the German practice of assigning

\begin{tabular}{|l|c|c|}
\hline \multicolumn{2}{|c|}{ TABLE 1 } \\
Job Responsibilities Most Frequently \\
Appearing in Job Postings \\
\hline Job Responsibilities & $\begin{array}{c}\text { Number of } \\
\text { Postings }\end{array}$ & $\begin{array}{c}\% \text { of } \\
\text { Postings }\end{array}$ \\
\hline Collection development \& management & 62 & $100 \%$ \\
\hline Managing collections & 41 & $66 \%$ \\
\hline Managing budget & 32 & $52 \%$ \\
\hline Collection analysis & 18 & $29 \%$ \\
\hline Information needs assessment & 16 & $26 \%$ \\
\hline Donor relations, gift and exchange & 16 & $26 \%$ \\
\hline Collection planning and policy & 15 & $24 \%$ \\
\hline Vendor relations & 15 & $24 \%$ \\
\hline Reference \& research assistance & 57 & $92 \%$ \\
\hline Instruction & 54 & $87 \%$ \\
\hline Developing guides & 34 & $55 \%$ \\
\hline Liaison work & 48 & $77 \%$ \\
\hline Outreach & 39 & $63 \%$ \\
\hline Cataloging & 25 & $40 \%$ \\
\hline Grant writing & 23 & $37 \%$ \\
\hline Supervising & 17 & $27 \%$ \\
\hline
\end{tabular}


book selection to subject specialist librarians ${ }^{35}$ A number of closely associated duties, including managing collections, managing budget, collection analysis, information needs assessment, donor relations, gift and exchange, collection planning and policy, and vendor relations are also specifically mentioned in most job postings.

Reference and research assistance (92\%) and instruction (87\%) are the next most frequently assigned responsibilities for East Asian studies librarians. Together with developing guides (55\%), a supplement to reference and research assistance and instruction, these responsibilities form the core information services an East Asian studies librarian is expected to provide in support of teaching and research at the universities.

The majority of the job postings (77\%) specify that an East Asian studies librarian is expected to work closely with particular academic departments and units as a liaison. This prevalent emphasis on liaison work implies the importance of subject expertise in East Asian studies librarianship. East Asian studies librarians need to use and develop their subject knowledge to establish a sustainable relationship with relevant academic departments and to offer specialized and in-depth user services. Outreach, which differs from liaison work, has become prevalent in job postings. A total of 39 postings (63\%) specified outreach as a responsibility for the East Asian studies librarian. East Asian librarians are often required to develop and implement outreach programs, such as creating physical and digital exhibits, coordinating social media, and hosting symposia, with an aim to reach the general public and promote the library's collection and services.

The present study also attempted to identify trends and changes in East Asian studies librarians' job responsibilities over time. It found that, overall, East Asian studies librarians have been gradually taking on an increasing number of job responsibilities during the past decade. Figure 3 shows the average number of responsibilities named in job postings for East Asian studies librarians has increased from 9.4 in 2008-2011 to 9.8 in 2012-2015 and 10.1 in 2016-2019.

Outreach was identified as the key factor that drove this constant increase in responsibilities. As shown in figure 4, outreach experienced a rapid increase, being mentioned in only 50 percent of job postings in 2008-2011 and in 84 percent of job postings in 2016-2019. It is with no doubt that outreach has become more incorporated into the job responsibilities.

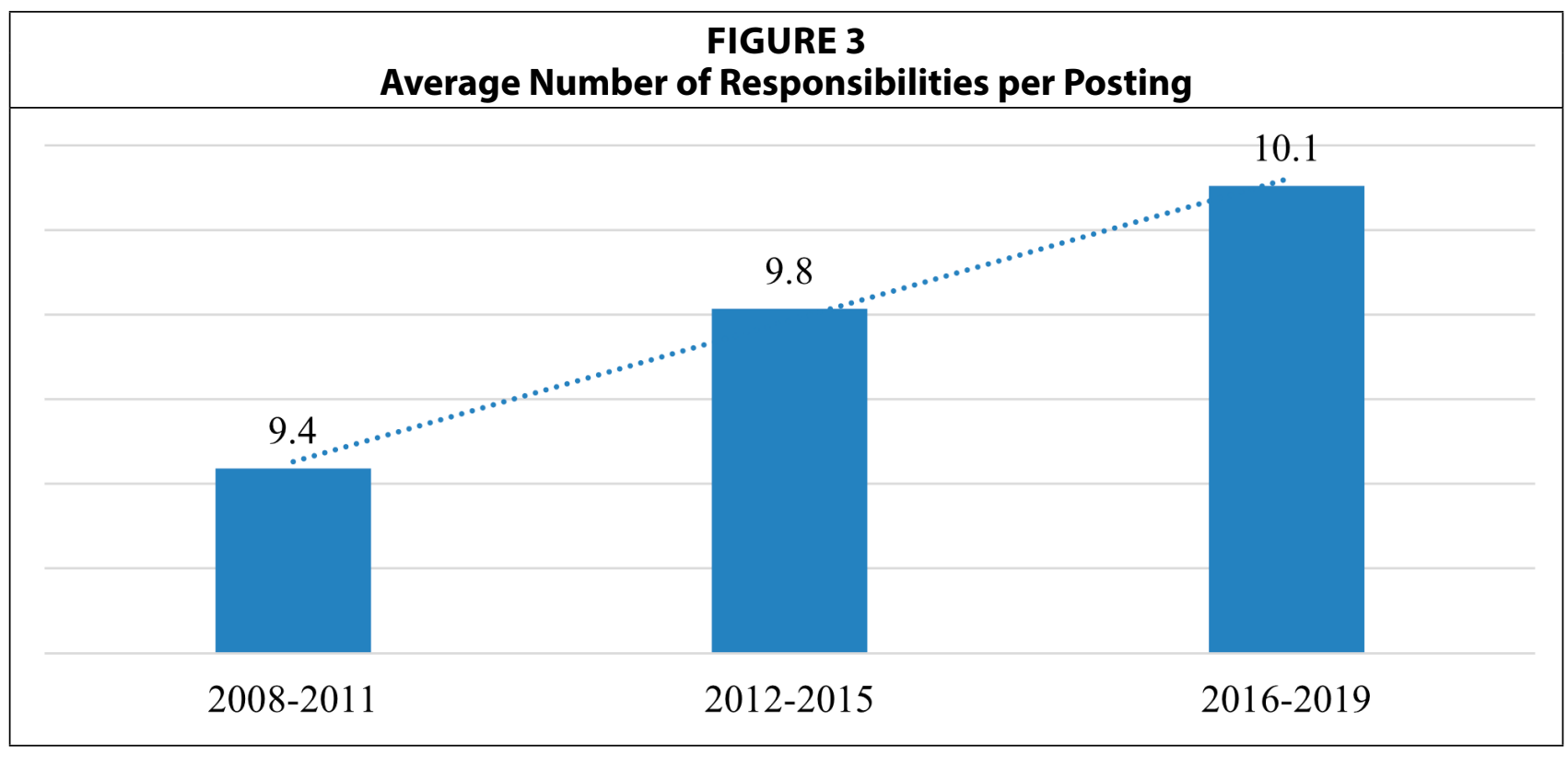




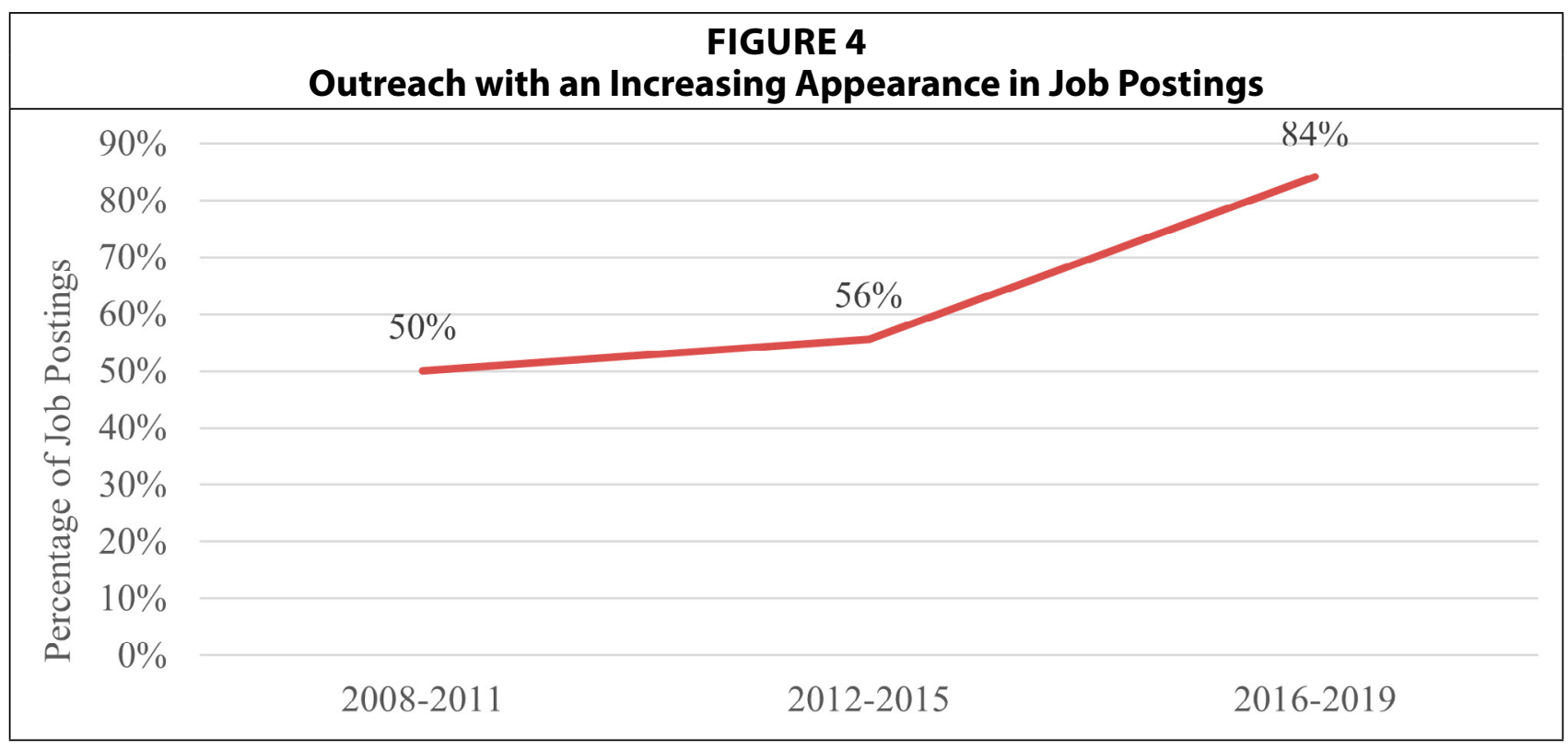

A similar finding of increasing job duties was observed in Alonso-Regalado and Ullen's examination of position announcements for LACS Librarians, where the number of duties jumped from an average of 4.8 in 1970-1989 to 6.25 in 1990-1999 and 7.85 in 2000-2007. ${ }^{36}$ Although the two studies have slight discrepancies in coding duties and responsibilities, ${ }^{37}$ it is reasonable to conclude the trend of an increasing number of duties for area studies subject librarians in the past 30 years. Given the added outreach responsibility and the needs of providing a variety of services for library users, this trend is strong and likely to continue in the future.

\section{Emerging Roles}

A close examination of all job descriptions suggests that relationship building and collaboration are emerging roles for East Asian studies librarians. Relationship building and collaboration are not only fundamental for East Asian studies librarians in fulfilling their job responsibilities but are also most sought to benefit both libraries and communities.

Relationship building is explicitly visible across all job responsibilities (see table 1), demonstrating that it is critically important for East Asian studies librarians to build and maintain a strong relationship with their constituents, including faculty, students, community, vendors, donors, and the general public.

Collaboration is highly valued and expected of East Asian studies librarians. Fifty-three (85\%) job postings mentioned that East Asian studies librarians need to work collaboratively with a wide variety of library units and librarians, including cataloging, acquisition, ILL, access services, other subject librarians, as well as newly emerged library units, such as digital humanities centers, digital initiatives, data services, and teaching and learning units. It suggests that the library profession is becoming increasingly specialized. As more and more functional teams including "technical, back-office operations (such as acquisitions and cataloguing), and generic front-of-house services (such as circulation) ${ }^{\prime \prime 38}$ are being formed, the fact that East Asian studies librarians are no longer able to work in separate silos is implicitly expressed in job advertisements.

In addition, a visual comparison of frequencies of collaboration-related words and synonyms in the job postings (see figure 5) vividly illustrates how expectations on collaboration have been evolving. ${ }^{39}$ 


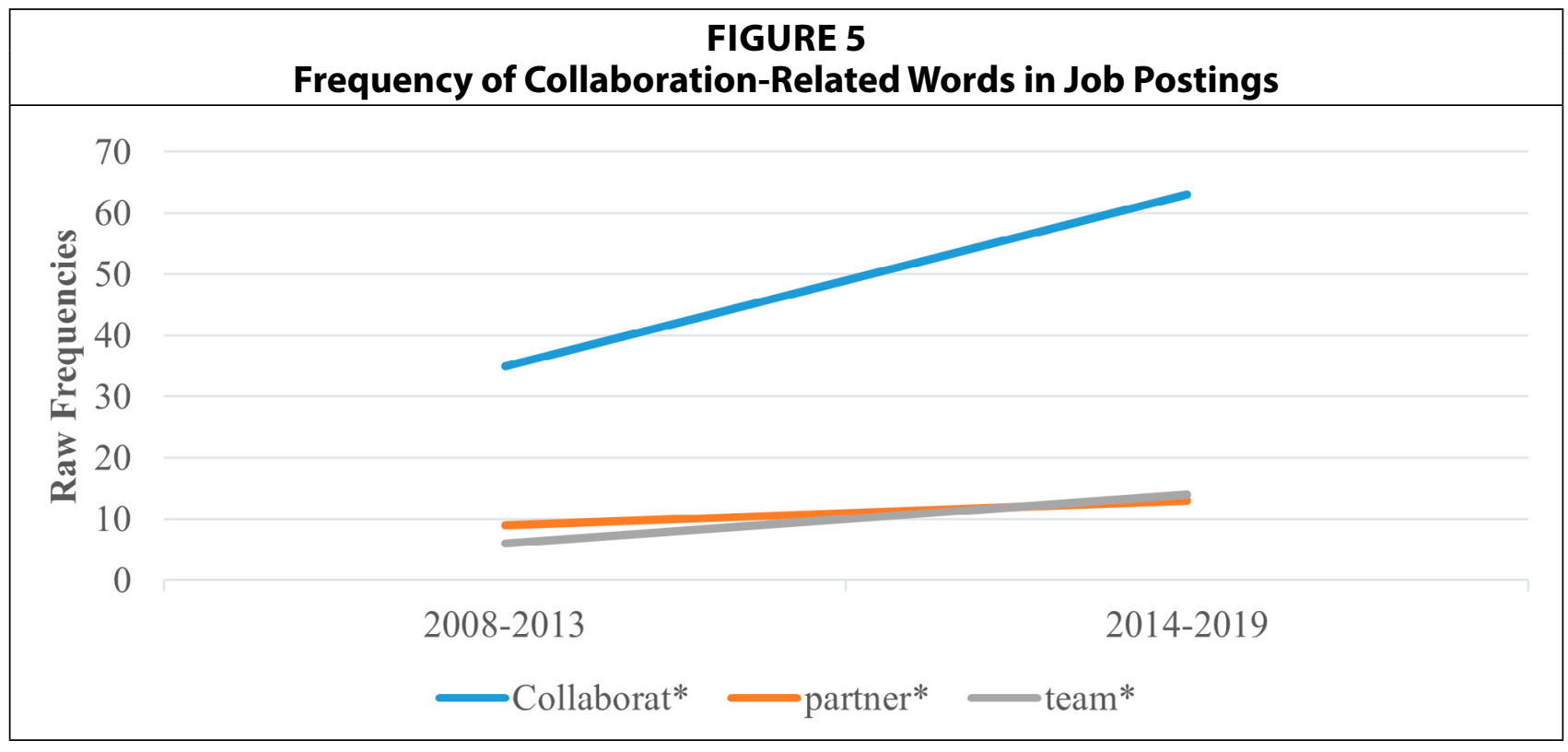

A growing requirement of professional development further reinforces the evolving roles of relationship building and collaboration for East Asian studies librarians. Forty-two (68\%) of the job postings state that the incumbents have to devote considerable efforts to professional development, building professional networks, and seeking collaborative opportunities specifically through active participation in local, regional, national, and international professional organizations and consortia.

\section{Qualifications}

The job qualifications section mostly consists of "required" (or "basic," "minimum") and "preferred" (or "desired") qualifications. Required qualifications define the appropriate education, training, experience, and competencies that an applicant must demonstrably possess to be considered as a candidate for an East Asian studies librarian position. Preferred qualifications describe employers' expectations of ideal candidates and thus serve as filters to seek outstanding and competitive applicants.

\section{Education}

The majority (95\%) of the job postings for East Asian studies librarians require an MLS degree. This is consistent with the main finding from Lynch and Smith, stating that "a master's degree from an ALA-accredited program has been adopted by the field as the appropriate professional degree for academic librarians." 40

Advanced degrees (MA or PhD) in East Asian studies fields tend to be treated as important as a degree in library and information sciences. Fifty-one (82\%) postings list advanced degrees in East Asian studies as the equivalent or alternative to required MLS degrees, and $38(61 \%)$ postings include advanced degrees in East Asian studies as desired and preferred education instead of MLS. The predominant attention on education and training in East Asian studies corresponds with the emphasis on subject knowledge reflected in the job descriptions section of the postings. An MA or PhD degree in a related academic discipline is typically considered a key indicator of sufficient subject expertise that candidates may have acquired. 


\section{Language}

High levels of proficiency in one or multiple East Asian languages (especially Chinese, Japanese, and Korean) are required by all job postings. Eleven postings (18\%) also require reading knowledge of classical East Asian languages, a written form of old languages widely used in East Asian rare books and historical documents. A strong command of East Asian languages is vital for East Asian studies librarians to perform their main responsibilities in collection development and user services, since they need to select materials in East Asian languages and communicate with vendors and researchers from East Asian regions.

\section{Knowledge, Experience, Skills, and Abilities}

By conducting a statistical analysis of the standardized corpus for required knowledge, experience, skills, and abilities, the authors discover that skills and abilities have been progressively occupying a larger proportion than knowledge and experience (see figure 6). During 2008-2010, less than half (44\%) of the requirements were devoted to skills (15\%) and abilities (29\%). By comparison, during 2017-2019, the total percentage of required skills (30\%) and abilities (35\%) rapidly increased to 65 percent, suggesting that the majority of required qualifications for East Asian studies librarians are now tied to applicants' competencies.

In contrast, the requirements for knowledge and professional experience, commonly used selection criteria for academic libraries to screen applicants, have dramatically decreased during the past decade. The total proportion for required knowledge and experience dropped sharply from 56 percent in 2008-2010 to 34 percent in 2017-2019.

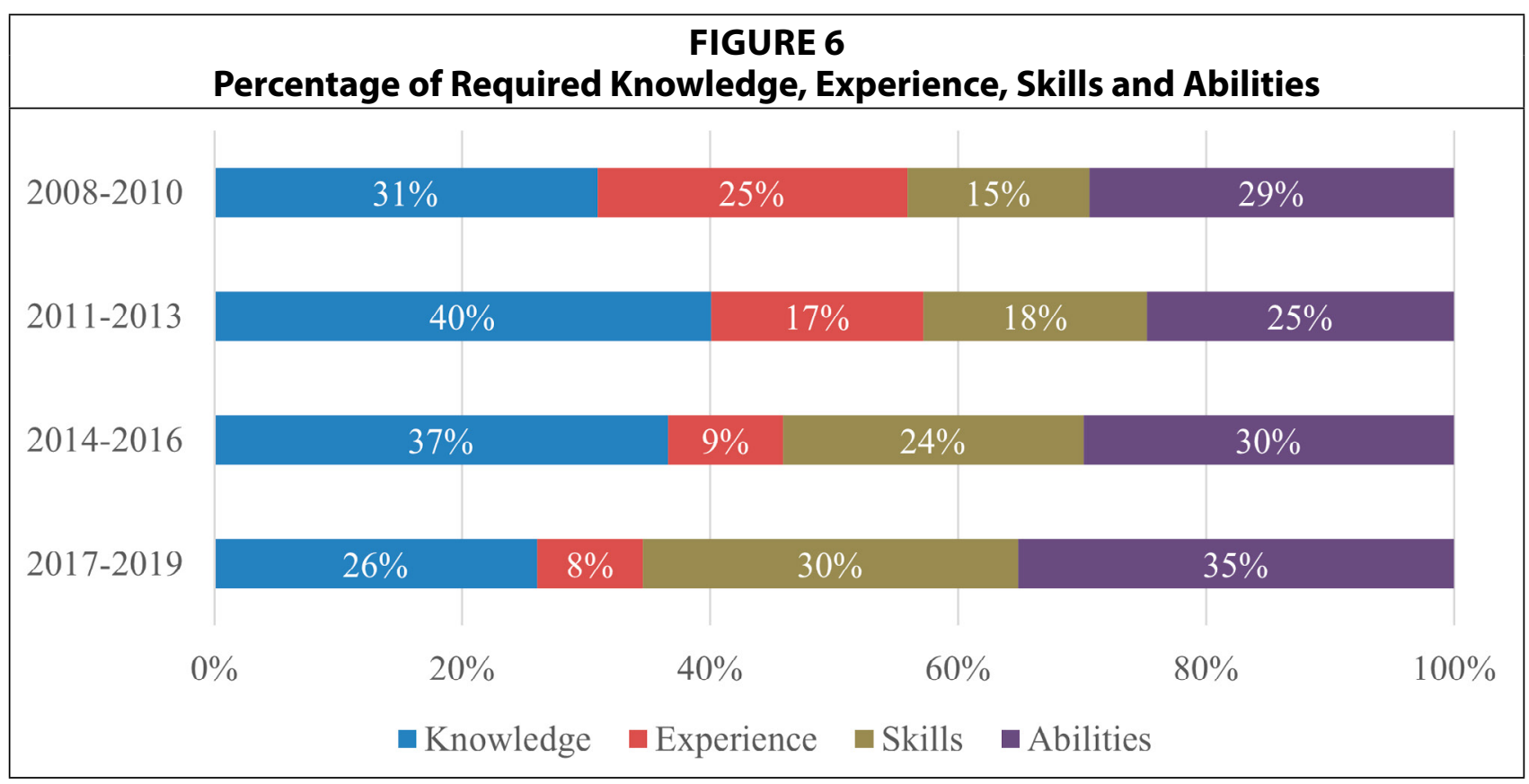

However, a statistical analysis of desired and preferred knowledge, experience, skills, and abilities in the job postings reveals that this section almost entirely consisted of knowledge and experience (see figure 7). Professional experience, a key criterion for academic libraries to identify more qualified and competitive applicants, appears more frequently in the preferred qualifications than required qualifications. As a matter of fact, $26(42 \%)$ job postings 
did not require professional experience, and five $(8 \%)$ postings did not include experience in the qualification section at all.

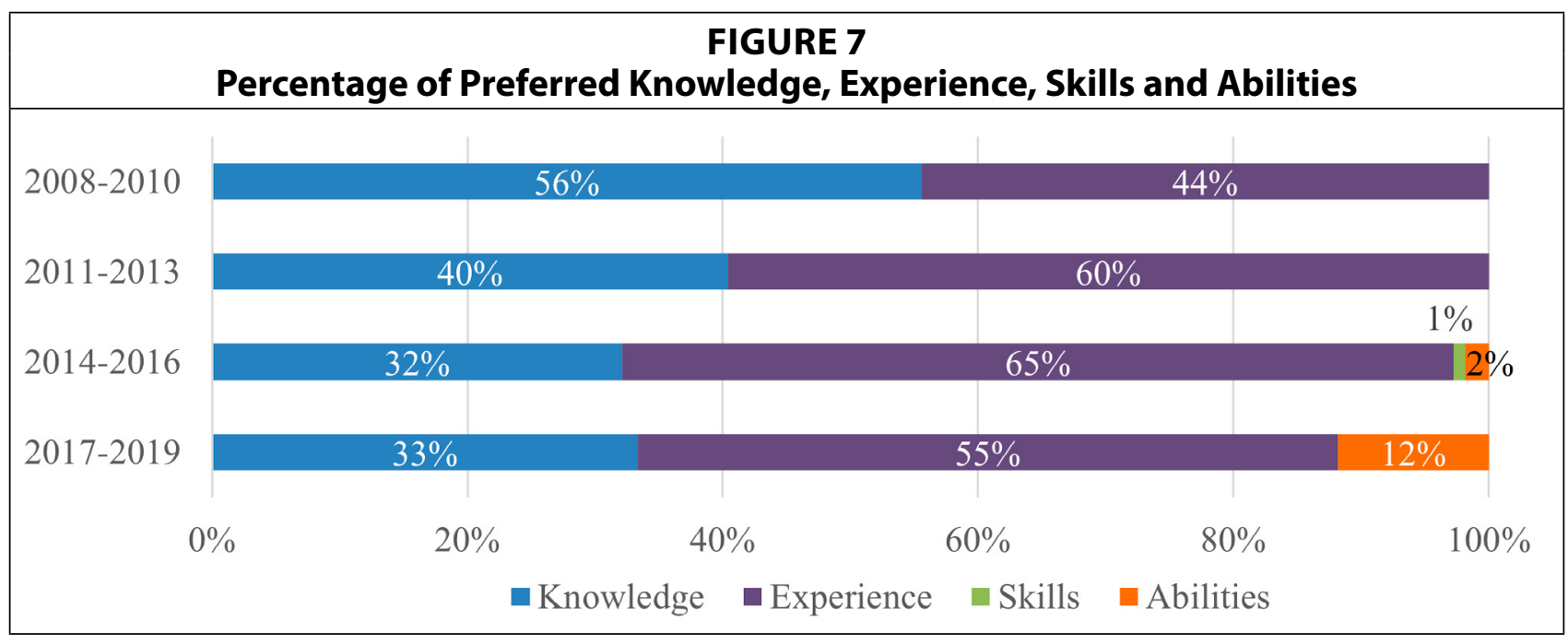

Frequently Required Skills and Abilities By analyzing the word frequencies of standardized terms for required skills and abilities, the authors noticed that the top frequently required skills and abilities (see table 2) are all generic and behavioral, focusing on employability attributes (such as communication skills, analytical skills, problemsolving skills, ability to work independently and effectively), and social intelligence (including interpersonal skills, ability to work collaboratively, and flexibility).

Given that relationship building and collaboration have become emerging roles for East Asian studies librarians, it is not surprising to see a greater emphasis on behavioral skills, which can be defined as "interpersonal, self-regulatory, and task-related behaviors that connect to successful performance in education and workplace settings," 43 in the required qualifications. The request for behavioral skills was discussed in several studies of librarian job advertisements during the early 2000s. Lynch and Smith claimed that behavioral skills, particularly oral and written communication skills, had emerged as new job requirements for academic librarian positions in the United States in the 1990s. ${ }^{44}$ Kennan et al. found that behavioral characteristics and interpersonal skills occurred very frequently in American job ads in $2004 .{ }^{45}$ The present study sufficiently proves that behavioral skills are among the most valuable assets to academic librarians.

On the other hand, there seems a lack of interest in hard, specific, and professional skills in the job postings. Only a few postings require abilities and skills that are closely related 
to the previously discussed main responsibilities for East Asian studies librarians, such as technology skills, presentation skills, ability to take initiative, and ability to perform duties in collection development and public services.

\section{Discussion}

\section{Changing Nature of Work}

Findings in this study demonstrate that East Asian studies librarians have been evolving from information curators in static and specialized silos to active user service providers in a changing and networked environment.

Much like other subject specialist librarians, the nature of the work of East Asian studies librarians has changed dramatically compared to subject specialists who began playing important roles in American university libraries fifty years ago. During the 1960s and 1970s, job duties for a subject specialist could be summarized in five basic categories: collection management, reference, faculty liaison, cataloging and classification, and bibliography. ${ }^{46}$ Accordingly, subject specialists, including East Asian studies librarians, were traditionally considered information curators and managers whose work centered on materials and information.

In the past decade, East Asian studies librarians have shifted the focus of their work toward users and thus have become service providers. Their responsibilities are expanding, most of which are related to the various services provided to library users. Significant requirements in reference and research assistance and instruction suggest that East Asian studies librarians need to be fully integrated into the research process of library users far beyond simply providing access to library materials. The fast-growing emphasis on liaison work and outreach indicates a trend for greater and deeper interaction and engagement with the user communities and the general public.

The emerging roles of relationship building and collaboration with constituents in and out of the library, and the progressive requirements of behavioral skills suggest a transition to a changing and networked environment. It becomes clear that East Asian studies librarians are expected to establish an extensive and in-depth network with all stake holders to successfully accomplish their main job duties. This may explain the rising demand for the behavioral skills required for East Asian studies librarians, especially the abilities and skills related to cooperation, communication, and interpersonal relationships.

The growing sophistication of East Asian studies is probably one of the important driving forces behind these changes and trends in East Asian librarianship. During the past couple of decades, East Asian studies scholarship has greatly shifted from a traditional literaturehistory-culture-emphasis to interdisciplinary and cross-disciplinary, from single-area/singleperiod-focused to cross-national and cross-cultural. "Such trends are getting more and more powerful to the point that the traditional scope of information needs for Asian Studies has been significantly broadened, diversified, and complexed." ${ }^{47}$ At the same time, with the rapid development of digital technology, a wide range of new research methods and tools have been introduced and incorporated into teaching and research. East Asian studies scholars are consistently engaged with very specialized digital methods and tools such as GIS data, text mining, information visualization, and social network analysis. In summary, as the teaching, learning, and research in East Asian studies are becoming more sophisticated and diverse, East Asian studies librarians will have to adjust their work priorities and practices to keep pace with the changing user needs. 


\section{Indistinct Core Competencies}

Findings from the qualification section reveal indistinct core competencies for East Asian studies librarians. All of the job postings require three sets of qualifications - knowledge in information sciences (MLS degrees), subject expertise in East Asian studies (advanced degrees in East Asian studies), and generic and behavioral skills and abilities. However, the three sets of qualifications are arguably inadequate for academic libraries to select qualified applicants to practice East Asian librarianship in a dynamic and connected digital world.

Evidently, ideal candidates for academic East Asian studies librarian positions would have excellent expertise in East Asian studies and solid training and experience in librarianship. However, it seems that academic libraries tend to be faced with discrepancies between the expected pool of applicants and ideal candidates for East Asian studies librarian positions, as prospective applicants are often those who hold advanced degrees in the fields of East Asian studies but with minimal training or experience in librarianship. Accordingly, knowledge and experience associated with librarianship are often being de-emphasized and compromised in the required qualifications for East Asian studies librarians to attract a broad and diverse pool of applicants. Nevertheless, desired candidates are still expected to have a solid background in academic librarianship, as clearly manifested in the preferred qualifications. Lack of professional standards for appropriate qualifications for East Asian studies librarians may be the reason to cause such an indistinctness in core competencies.

It is also worth noting that an MLS degree does not guarantee adequate training in all the knowledge and skills that an information professional should possess before entering the workforce. This could be detected from the ALA Standards for Accreditation of Master's Programs in Library and Information Studies, ${ }^{48}$ which describes the curriculum of an MLS program. Although the 2015 Standards has reflected changes and trends in the profession, like what Lynch and Smith has noticed on the previous edition, ${ }^{49}$ it still lacks any mention of the behavioral and generic skills necessary for information professionals in their new work environment. This is probably one reason why the requirements for such skills and abilities are so extensive in the job postings. But there is no consensus on what type of generic and behavioral skills and abilities are needed and where East Asian studies librarian applicants can obtain them.

\section{Suggestions}

As the professional association for East Asian libraries and librarians, the Council on East Asian Libraries (CEAL) may consider creating guidelines and statements to define knowledge and competencies to be possessed by East Asian librarians in the new digital age, as well as developing training opportunities for East Asian librarians to improve and advance professionalism in East Asian librarianship. CEAL could form a taskforce to research what has been done by other professional organizations in North America, such as Art Libraries Society of North America, Music Library Association, and others, and develop their own documents and programs.

It is high time for library schools to consider developing and enhancing curriculum relevant to East Asian librarianship and, more broadly, area studies librarianship. These efforts will help to ensure sustainable development in this important field of academic librarianship, especially considering that there has been limited curricula related to area studies librarianship, not to mention East Asian librarianship, in MLS programs in the past. 


\section{Conclusion}

Our analysis of job postings for East Asian studies librarian positions from 2008 to 2019 reveals interesting trends in the East Asian studies librarianship. First, major responsibilities for East Asian studies librarians have expanded to include collection development and management, reference and research assistance, instruction, liaison work, and outreach. Outreach was identified as a key factor that drove the constant increase in responsibilities. Second, relationship building and collaboration are emerging roles for East Asian studies librarians. The study demonstrates that building a professional network and seeking collaborative opportunities are fundamental to East Asian studies librarianship. Third, the study discovers that skills and abilities have been progressively occupying a larger proportion than knowledge and experience in the required qualifications for East Asian studies librarian positions. Top frequently required abilities and skills are all generic and behavioral. Last but not least, the study also shows that professional experiences are often preferred rather than required. Overall, these trends indicate that East Asian Studies librarians are evolving from information curators and managers to active user service providers in a highly connected digital world. The results also provide insight into the broader subject librarianship. Changes in academic libraries seem to impact East Asian studies librarians in somewhat the same way other subject librarians are affected.

The increasing emphasis on outreach, collaboration, and behavioral skills for East Asian studies librarians indicates a need for future research on the changing role of subject expertise for East Asian studies librarianship and, more broadly, area studies librarianship. Research in this area could address intriguing questions outside the scope of this study, such as why do academic libraries still tend to maintain the traditional job responsibilities and qualifications for areas studies librarians while rapidly transforming and reconfiguring other positions? What benefits and values have a "hybrid model" that combines elements of subject experts and functional specialists brought to academic librarianship?

\section{Notes}

1. James G. Neal, "Raised by Wolves: Integrating the New Generation of Feral Professionals into the Academic Library," Library Journal 131, no. 3 (2006): 42-44.

2. Fred J. Hay, "The Subject Specialist in the Academic Library: A Review Article," Journal of Academic Librarianship 16, no. 1 (1990): 11-17.

3. Hay, "The Subject Specialist in the Academic Library," 11-17.

4. For more information on the divisional library structure, see Hay, "The Subject Specialist in the Academic Library," 11-17.

5. Catherine Hoodless and Stephen Pinfield, "Subject vs. Functional: Should Subject Librarians Be Replaced by Functional Specialists in Academic Libraries?" Journal of Librarianship \& Information Science 50, no. 4 (December 2018): 345-60, https://doi.org/10.1177/0961000616653647.

6. Tyler Walters, Katherine Skinner, and Association of Research Libraries, "New Roles for New Times: Digital Curation for Preservation," Distributed by ERIC Clearinghouse (2011), https://files.eric.ed.gov/fulltext/ ED527702.pdf; Sheila Corrall, "Designing Libraries for Research Collaboration in the Network World: An Exploratory Study," LIBER Quarterly 24, no. 1 (2014): 17-48, https://doi.org/10.18352/lq.9525.

7. Neal, "Raised by Wolves," 42-44.

8. David W. Reser and Anita P. Schuneman, “The Academic Library Job Market: A Content Analysis Comparing Public and Technical Services," College E Research Libraries 53, no. 1 (1992): 49-59, https://doi.org/10.5860/ crl_53_01_49.

9. Reser and Schuneman, "The Academic Library Job Market," 51.

10. Penny M. Beile and Megan M. Adams, "Other Duties as Assigned: Emerging Trends in the Academic Library Job Market," College \& Research Libraries 61, no. 4 (2000): 336-47, https://doi.org/10.5860/crl.61.4.336. 
11. Therese F. Triumph and Penny M. Beile, "The Trending Academic Library Job Market: An Analysis of Library Position Announcements from 2011 with Comparisons to 1996 and 1988," College E Research Libraries 76, no. 6 (2015): 716-39, https://doi.org/10.5860/crl.76.6.716.

12. Triumph and Beile, "The Trending Academic Library Job Market," 716.

13. Beverly P. Lynch and Kimberley Robles Smith, "The Changing Nature of Work in Academic Libraries," College E Research Libraries 62, no. 5 (2001): 407-20, https://doi.org/10.5860/crl.62.5.407.

14. Lynch and Smith, "The Changing Nature of Work in Academic Libraries," 418.

15. Paul W. Grimes and Marybeth F. Grimes, "The Academic Librarian Labor Market and the Role of the Master of Library Science Degree: 1975 through 2005," Journal of Academic Librarianship 34, no. 4 (2008): 332-39, https://doi.org/10.1016/j.acalib.2008.05.023.

16. Janie M. Mathews and Harold Pardue, "The Presence of IT Skill Sets in Librarian Position Announcements," College E Research Libraries 70, no. 3 (2009): 250-57, https://doi.org/10.5860/0700250.

17. Li Zhang, "Foreign Language Skills and Academic Library Job Announcements: A Survey and Trends Analysis, 1966-2006," Journal of Academic Librarianship 34, no. 4 (2008): 322-31, https://doi.org/10.1016/j.acalib.2008.05.005.

18. Kristen Radsliff Rebmann, Simone Molitor, and Bonnie Rainey, "Distance Learning Skills and Responsibilities: A Content Analysis of Job Announcements 1996-2010," Journal of Library \& Information Services in Distance Learning 6, no. 2 (April 2012): 100-16, https://doi.org/10.0.4.56/1533290X.2012.693904.

19. Jennifer Ferguson, "Additional Degree Required? Advanced Subject Knowledge and Academic Librarianship," portal: Libraries and the Academy 16, no. 4 (2016): 721-36, https://doi.org/10.1353/pla.2016.0049.

20. For example, Joe C. Clark, "Job Trends in Music Librarianship: A Nine-Year Analysis of the Music Library Association's Job List," Notes 69, no. 1 (September 2012): 44-58; Ann W. Copeland, "The Demand for Serials Catalogers: An Analysis of Job Advertisements, 1980-1995," Serials Librarian 32, no. 1/2 (1997): 27-37, https://doi. org/10.1300/J123v32n01_03; Jung-ran Park and Caimei Lu, "Metadata Professionals: Roles and Competencies as Reflected in Job Announcements, 2003-2006," Cataloging \& Classification Quarterly 47, no. 2 (April 2009): 145-60; Myung-Ja Han and Patricia Hswe, "The Evolving Role of the Metadata Librarian," Library Resources \& Technical Services 54, no. 3 (July 2010): 129-41.

21. Elizabeth Skene, "Shooting for the Moon: An Analysis of Digital Initiatives Librarian Job Advertisements," Digital Library Perspectives 34, no. 2 (April 2018): 84-90.

22. Jingfeng Xia and Yue Li, "Changed Responsibilities in Scholarly Communication Services: An Analysis of Job Descriptions," Serials Review 41, no. 1 (January 2015): 15-22.

23. Jingfeng Xia and Minglu Wang, "Competencies and Responsibilities of Social Science Data Librarians: An Analysis of Job Descriptions," College E Research Libraries 75, no. 3 (May 2014): 362-88, https://doi.org/10.5860/ crl13-435.

24. John D. Shank, "The Blended Librarian: A Job Announcement Analysis of the Newly Emerging Position of Instructional Design Librarian," College E Research Libraries 67, no. 6 (2006): 515-24, https://doi.org/10.5860/ crl.67.6.514.

25. Gary W. White, "Academic Subject Specialist Positions in the United States: A Content Analysis of Announcements from 1990 through 1998," Journal of Academic Librarianship 25, no. 5 (1999): 372-82, https://doi. org/10.1016/S0099-1333(99)80056-1.

26. Jesús Alonso-Regalado and Mary K Van Ullen, "Librarian for Latin American and Caribbean Studies in U.S. Academic and Research Libraries," Library Resources \& Technical Services 53, no. 3 (2009): 139-58, https://doi. org/10.5860/lrts.53n3.139.

27. Alonso-Regalado and Van Ullen, "Librarian for Latin American and Caribbean Studies in U.S. Academic and Research Libraries," 151.

28. Michael Levine-Clark and Toni M. Carter, ALA Glossary of Library and Information Science (Chicago, IL: American Library Association, 2013), 246.

29. "Jobs," Council on East Asian Libraries, accessed December 31, 2019, https://www.eastasianlib.org/newsite/ category/all/jobs/; "CEAL Jobs: Recent East Asian Library-related Jobs, Presented by CEAL," Council on East Asian Libraries, accessed November 30, 2019, http://cealjobs.blogspot.com/.

30. "Messages," Council on East Asian Libraries, accessed December 31, 2019, https://lists.unc.edu/ $\mathrm{read} /$ ?forum=eastlib\&amp;sb=1.

31. Ray Harper, "The Collection and Analysis of Job Advertisements: A Review of Research Methodology," Library and Information Research 36, no. 112 (2012): 29-54, https://doi.org/10.29173/lirg499.

32. Kimberly A. Neuendorf, The Content Analysis Guidebook (Thousand Oaks, CA: Sage Publications, 2016).

33. MonkeyLearn, accessed July 1, 2020, https://app.monkeylearn.com/.

34. The average accuracy rate for knowledge, skills, abilities, and experience that constitute the core of the 
raw texts from the qualification section is 87 percent.

35. Lynn B. Williams, "Subject Knowledge for Subject Specialists: What the Novice Bibliographer Needs to Know," Collection Management 14, no. 3/4 (September 18, 1991): 31-47, https://doi.org/10.1300/J105v14n03_04.

36. Alonso-Regalado and Van Ullen, "Librarian for Latin American and Caribbean Studies in U.S. Academic and Research Libraries," 150.

37. Alonso-Regalado and Van Ullen, "Librarian for Latin American and Caribbean Studies in U.S. Academic and Research Libraries," 158.

38. Sheila Corrall, "Designing Libraries for Research Collaboration in the Network World: An Exploratory Study," LIBER Quarterly 24, no. 1 (2014): 17-48, https://doi.org/10.18352/lq.9525.

39. Note that there are equal numbers of job postings in the time periods 2008-2013 and 2014-2019.

40. Lynch and Smith, "The Changing Nature of Work in Academic Libraries," 407.

41. This standardized term includes variant forms of the word collaborative and its synonyms such as "cooperative" and "team."

42. This standardized term refers to the ability to handle diverse environments, groups, and/or backgrounds.

43. Daniel M. Elchert et al., and Inc ACT, The Importance of Behavioral Skills and Navigation Factors for Education and Work Success: ACT Insights in Education and Work Series, Distributed by ERIC Clearinghouse (2017).

44. Lynch and Smith, "The Changing Nature of Work in Academic Libraries," 407.

45. Mary Anne Kennan et al., "Changing Workplace Demands: What Job Ads Tell Us," Aslib Proceedings 58, no. 3 (2006): 179-96, https://doi.org/10.1108/00012530610677228.

46. Hay, "The Subject Specialist in the Academic Library," 11-17.

47. Xiang Li, "A Study of Research Practices of Scholars in Asian Studies at the University of Colorado Boulder" (2017), https://scholar.colorado.edu/libr_facpapers/107.

48. Committee on Accreditation of the American Library Association, "Standards for Accreditation of Master's Programs in Library and Information Studies" (2015), www.ala.org/educationcareers/sites/ala.org.educationcareers/files/content/standards/Standards_2015_adopted_02-02-15.pdf.

49. Lynch and Smith, "The Changing Nature of Work in Academic Libraries," 414. 